\title{
Characterization of CD4+ Lymphocyte From Bone Marrow Stem Cell Using Indirect Immunofluoresence For HIV \& AIDS Treatment
}

\author{
Purwati $^{1 *}$, Nasronudin ${ }^{2}$, Fedik A. Rantam ${ }^{3}$ \\ ${ }^{1}$ Stem Cell Research and Development Center, Universitas Airlangga, Surabaya, Indonesia.. \\ ${ }^{2}$ Airlangga University Teaching Hospital, Universitas Airlangga, Surabaya, Indonesia \\ ${ }^{3}$ Faculty of Veterinary Medicine, Universitas Airlangga, Surabaya, Indonesia. \\ *Corresponding author: purwatipanpan@yahoo.com
}

\begin{abstract}
Acquired immune deficiency syndrome (AIDS) is caused by Human Immunodeficiency Virus (HN). At the beginning of infection, gpl20 virus interacts with CD4 receptor at the surface of the target cell. The interaction between gpI20 and CD4 leads to the occurrence of the binding of specific chemokine receptor CXCR4 and CCR5, which are also present on the membrane of the target cell. Therefore, CCR5 arid CXCR4 also determine the fate of the target cell. It is the performance of CCR5 and CXCR4, guided by controlling gene that determines susceptibility or resistance to HN infection. Coding gene CCR5 may mutate to become protective or resistant against HTV infection. In homozygote individuals, it tends to be resistant against infection while in heterozygote individuals it tends to be susceptible to HN infection. Objective: To characterize TCD4 lymphocyte in the next that is resistant against HN infection by using gene therapy deletion 32 CCR5 to use for HTV \& AIDS treatment. Method: Sample collection, mononucleated cell collection, lymphocyte culture, CD4 identification, CCR5 variance analysis, cocultivation with PBMC HN and comparison to control. Result: This study was performed in several steps, such as mononucleated cell isolation, followed with cell culture, lymphocyte purification, lymphocyte and CD4 expression identification. Conclusion: Lymphocyte T CD4 had been mature after seven passages, once passage is about 5 days so for maturity lymphocyte T CD4 need 35 days and that cell as be candidate to resistant against $\mathrm{HN}$ infection by using gene therapy deletion 32 CCR5 to use for HN \& AIDS treatment.
\end{abstract}

Key words: characterization, Lymphocyte T CD4, HIV \& AIDS.

\section{INTRODUCTION}

Acquired immune deficiency syndrome (AIDS), caused by Human Immunodeficiency Virus (HIV), is a life threatening infectious disease. Human Immunodeficiency Virus (HIV) is an RNA virus from the family Retrovirus and subfamily Lentiviridae. There are two HIV serotypes, the HIV-1 and HIV-2. Morphologically, HIV-1 has around shape arid consists of the core and the envelope (Levinson and Jawetz, 2003).

At the beginning of infection, gp120 virus interacts with $\mathrm{CD} 4$ receptor at the surface 
of the target cell. The interaction between gp120 and CD4 leads to the occurrence of the binding of specific chemokine receptor CXCR4 and CCR5, which are also present on the membrane of the target cell. Therefore; CCR5 and CXCR4 also determine the fate of the target cell. It is the performance of CCR5 and CXCR4, guided by controlling gene that determines susceptibility or resistance to HIV infection. Coding gene CCR5 may mutate to become protective or resistant

\section{MATERIALS AND METHODS}

This was an experimental study on in vitro allogenic stem cell transplantation using TCD4 bone marrow lymphocyte from donor for delegation in CCR5, which could be applied to HIV \& AIDS patients. Samples were taken from bone marrow of healthy donors. The inclusion criteria were aged 18-30years, healthy, having no systemic or degenerative disease, no infectious disease, and signing the informed

\section{Sample collection}

Sample was taken from donors who had kinship relations (sibling). After 5cc of blood was taken from the donors BMA, we performed

\section{Mononucleated isolation}

BMA was centrifugated at $1600 \mathrm{rpm}$ for 15 minutes, and gently entered into $15 \mathrm{cc}$ tube containing Ficol from the side of the tube. After being centrifugated, the huffy coat was isolated by putting in the pipette, sucked, contained against HIV infection In homozygote individuals, it tends to be resistant against infection, while in heterozygote individuals it tends to be susceptible to HIV infection (Brooke et al., 2002; Levy, 1994)

The objective of this study was to characterize TCD4 lymphocyte in the next that is resistant against HIV infection by using gene therapy deletion 32 CCR5 to use for HIV \& AIDS treatment.

consent. The exclusion criteria were the 'presence of other infectious diseases, the presence of severe underlying diseases (DM, $\mathrm{CKD}$, heart failure, hepatic failure, hepatic cirrhosis, etc), aged more than 30 years, and illiterate. The sites of the study were at $\mathrm{Dr}$ Soetomo Hospital, Surabaya, and Institute of Tropical Disease, Airlangga University, Surabaya.

mononucleated cell isolation using Ficol Histopaque gradient 1.007, followed with culture (Fedik et al., 2009).

within the Eppendorf tube, washed with PBS, cultured, and kept within-5\% C02 incubator using alpha MEM medium containing 25\% FSB serum (Fedik et al., 2009). 
Lymphocyte culture

After the third day, it was cultured and hematopoietic stem-cell supernatant was separated and centrifugated at $1600 \mathrm{rpm}$ for 5 minutes in 10degree C. After the supernatant was removed, the pellet was resuspended with

CD4 identification

An indicator was required to identify the maturation of the cell. In this case, the indicator was CD4. The identification was performed as follows: The lymphocyte culture was. harvested and put into $15 \mathrm{cc}$ tube, and fixed by means of

\section{RESULT}

In the first year of this study, several stages have been performed, such as mononucleated cell isolation, followed with cell culture, lymphocyte purification, lymphocyte and CD4 expression identification.

Isolation and culture of mononucleated cell

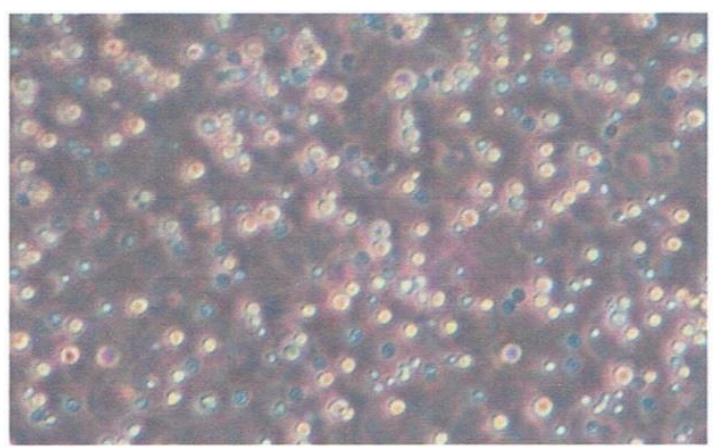

Figure 1. Cell was isolated using Ficoll histopaque 1.077 and cultured, observed under inverted microscope in IQ $\mathrm{x}$ magnification. growing medium containing 20\% FBS and penstrep antibiotics. After resuspension, it was entered into Petri dish and kept within 5\% C02 incubator (Fedik et al., 2009).

methanol. After 15 minutes, anti T-CD4 cell reagent was added, labeled with Fit C. Subsequently, it was washed with PBS, and dripped onto object glass and analyzed under fluorescence microscope (Fedik et al., 2009).

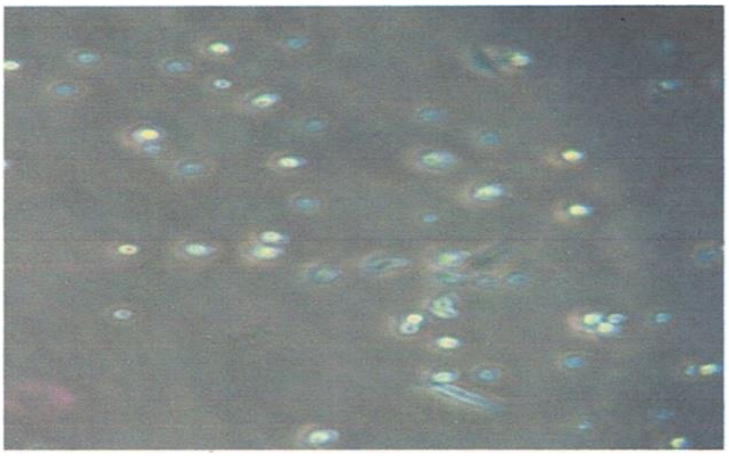

Figure 2. The cell, 24 hours after washing and observed under inverted microscope in $10 \mathrm{x}$ magnification. Mononucleated cells attached in Petri dish

\section{Lymphocyte Purification}

Three days after culture, supernatant that containing hematopoietic stem cell was separated and centrifugated in $1600 \mathrm{rpm}$ for 5 minutes in 10 degree $\mathrm{C}$. After the supernatant was removed, the pellet was resuspended with growing medium containing 20\% FBS serum and penstrep antibiotics. After resuspension, it was put onto petri dish and kept within 5\% C02 incubator. 


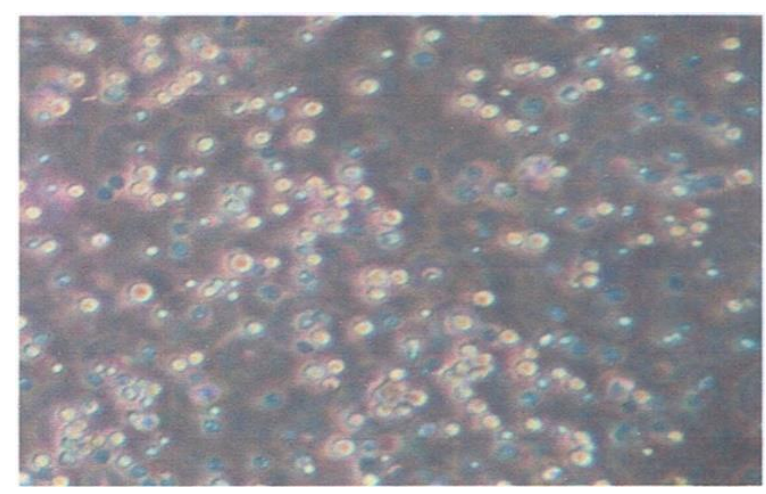

Figure 3. Mononucleated cell culture observed under inverted microscope in $10 \mathrm{x}$ magnification.

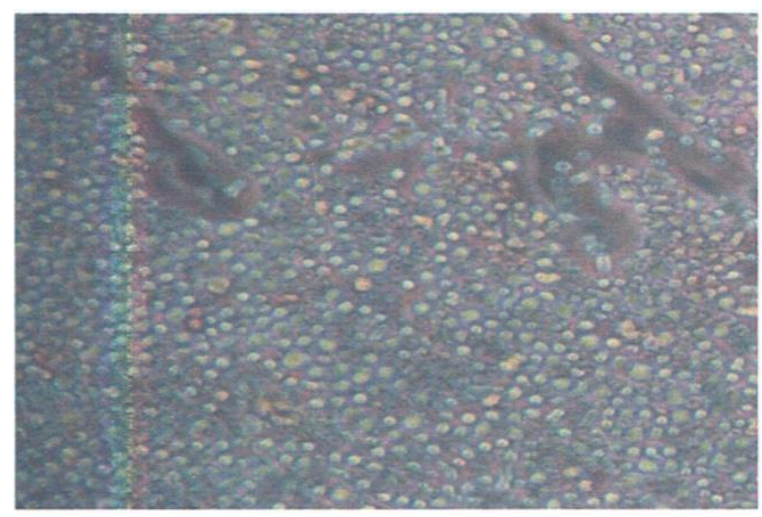

Figure 4. Day 5, after hematopoietic cells were cultured, mesenchymal cells also grew between hematopoietic cells, observed under inverted microscope in $10 \mathrm{x}$ magnification.

Then, the hematopoietic cells were separated from mesenchymal cells.

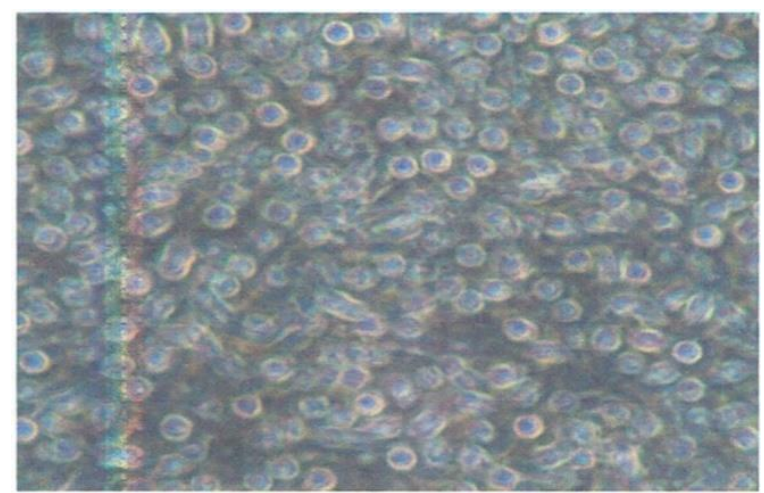

Figure 5. Lymphocytes are cultured until ready to be cocultivated, observed under inverted microscope in $10 \mathrm{x}$ magnification.

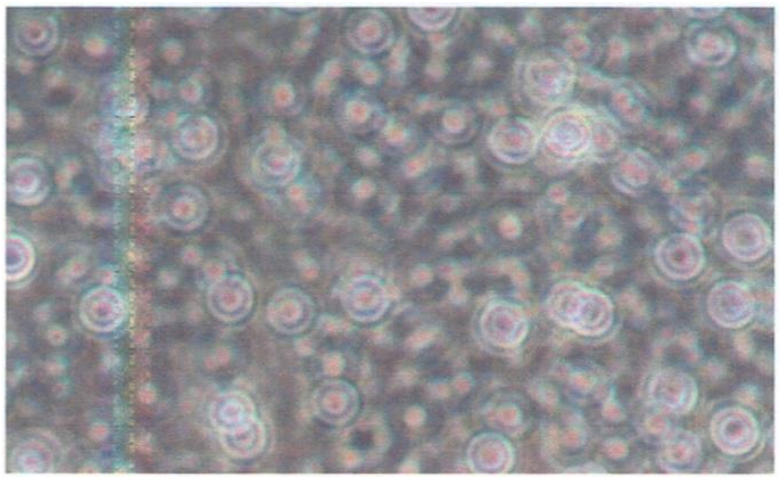

Figure 6. mature lymphocytes are identified with CD4, observed under inverted microscope in $10 \mathrm{x}$ magnification

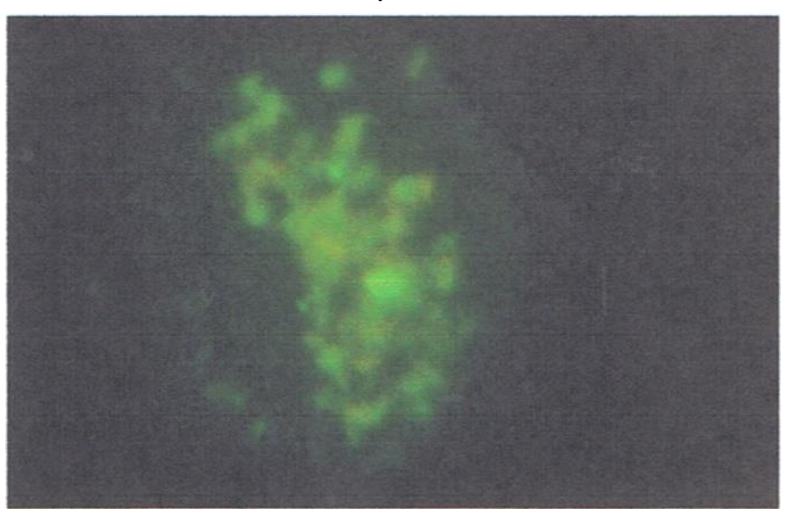

Figure 7. After being harvested, the lymphocytes were put into $15 \mathrm{cc}$ tube and fixed with methanol. After 15 minutes, it is added with anti T-CD4 cell reagent labeled with Fit $\mathrm{C}$. it was washed with PBS, and dropped onto glass object and analyzed under fluorescence microscope.

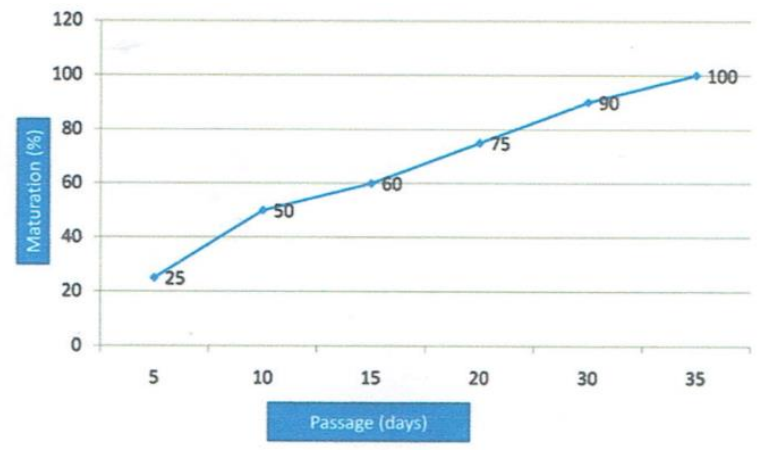

Figure 8. Lymphocyte maturation $100 \%$ achieved on 35 days (seven passages) 


\section{DISCUSSION}

After performing studies in several stages, including isolation, identification, characterization, significant results were found, such as:

In this stage, after isolation we obtained cells as many as 2 x 10(7) per $3 \mathrm{ml}$ BMA. However, in this stage, after isolation and cultivation, many cells could not grow. This was likely because the process between sample collecting and isolation needed faster time and more appropriate temperature as required by the cells, and medium $\mathrm{pH}$ should have been more suitable to the characteristics of the cell. This was proved during the culture with Petri dish, in which many cells could not develop due to less optimum adherence between cells and petri dish's matrix. Another point that should have been noticed in isolating process was sample collection. Sample collecting should use proper medium transport, so that cell death can be suppressed. This can also be seen in the result of mononucleated cell isolation with cell grown on petri dish whose growth could reach more than $80 \%$ (Fedik et al., 2009; Sriram and Rammesh, 2008).

Buffy coat containing mononucleated cell was separated or washed with PBS, deeper attention should be given to the $\mathrm{pH}$ of 'the PBS or washing medium, because if it is too acid or too alkali, it would cause membrane damage, resulting in difficult adherence of the cells to petri dish. This less capability of adherence results in cell death. Another point that -should be noted is that when centrifugation is undertaken above $3600 \mathrm{rpm}$, adherence between cell often occurs.so that when resuspension is undertaken, cell membrane would be damaged, preventing the cell to adapt and adhere to the base of the petri dish (Dinsmore et al., 1996; Fedik et al., 2009).

In hematopoietic cell culture, the isolation should be carried out carefully to prevent mesenchymal cell contamination in order to obtain optimum cells development, because those cells would become innate cells (innate immunity, such as macrophage, monocyte, PMN, eosinophil, and basophil). Therefore, this cell has better differentiation power. In this study, we did not carry out characterization in products that have important role, such as TGF, TNF, IL, IFN, and etc (Oppenheim and Ruscetti, 2003) that serve as signaling transducer as well as immune cell triggering that enhances cell differentiation. This would be undertaken in the next step. Nevertheless, after culture was made on the result of the separation between mesenchymal and hematopoietic cells, contaminants are still found. Therefore, in this stage further purification was required, and the result can be seen in figure 7 .

In this stage, after lymphocyte purification was done and developed with growth medium, significant development was found as proved from CD4 receptor examination, which was found in almost alllymphocytes. This indicates that the cell underwent almost perfect differentiation, characterized by high density of CD4 expression. The result can be seen in Figure I0, which is using irnmunofluorescence 
approach. From the result it could be indicated that there was significant $T$ lymphocyte differentiation, even though in this study the cell had been differentiated and could be used as a basis for immunodeficiency

\section{CONCLUSION}

Lymphocyte T CD4 had been mature after seven passages, once passage is about 5 days so for maturity lymphocyte T CD4 need 35 days and

\section{REFERENCES}

Brooke SM, McLaughlin JR, Cortopassi KM, Sapolsky RM.2002. Effect of gpl20 on glutatione peroxidase activity in cortical cultures and the interaction with steroid hormones. J Neurochem 81: 1-24

Dinsmore J, Ratliff J, Deacon T. 1996. Embryonic stem cell differentiated in vitro as a novel source of cells for transplantation Cell Transplant, 5: 13143

Folks TM, Hart CE. 1997.The Life Cycle of Human lmmunodeficiency Virus Type 1 ln: AIDS. Fourth Edition. Editors: De Vita VT, Hellman S, Rosembrk SA. Lippincott - Raven, Philadelphia, pp. 2943

Hirschel B. 2003. HN infection. In: Infectious diseases in 30 days. Editor: Southwick FS. McGraw-Hill, Medical Publishing Division, USA, p. 477-524

Jaroslaw C, Cornelia W, Alexandra R. 2003. Potential of embryonic and adult stem cells in vitro. Biol Chem, 384: 1391409 therapy, such as in HIV \& A1DS. Another point to note is the CTL product has an important role in the process of apoptosis. This indication can be used as the marker of activity of lymphocyte against the exposure to foreign gene.

that cell as be candidate to resistant against HIV infection by using gene therapy deletion 32 CCR 5 to use for HIV \& AIDS treatment.

Koolman J, Rohm KH .2001. Daur Hidup Virus HIV. Dalam: Atlas Berwama dan Teks Biokimia. Edisi Alih Bahasa: Wanandi SI. Editor: Sadikin. Penerbit Hipokrates, Jakarta, p. 358-359

Ledru E, Lecoeur H, Garcia S, Debord T, Gougeon ML. 1998. Differential susceptibility to activation-induced apoptosis among peripheral Th1 subsets: Correlation with Bcl-2 expression and consequences for AIDS pathogenesis. The Journal of Immunology. 160: 31943206

Levinson W, Jawetz E. 2003. Human Immunodeficiency Virus. In: Medical Microbiology and Immunology. Seventh Edition.Editor: Levinson W, Jewetz E. International Edition. Singapore, p.286-294.

Levy JA. 1994. Intracellular Control of HIV replication. In: HIV and the Pathogenesis of AIDS. ASM press, Washington DC. p. $59-70$ 
Luzuriaga K, Sullivan JL. 1997. Transmission of the human immunodeficiency virus from mother to the fetus and infant. In: AIDS etiology, diagnosis, reatment and prevention. Fourth Edition. Editor: De Vita VT, Hellman S, Rosenberg SA Philadelphia, p. 167-173

Mandel GL. 2000. Human immunodeficiency virus. In: Essential atlas of infectious diseases, 2nd ed. Editor: Bleck TP, Brook I, Fekety R, Lorber B, Mildvan D. Philadelphia: Current Medicine, Inc, p.6-7.

Metcalf JA, Davey RT, Lane HC. 1997. Acquired Immunodeficiency Syndrome: Serologic and Virologic Tests. In: AIDS Fourth Edition. Editors: De Vita VT, Hellman S, Rosernbrk SA. LippincottRaven, Philadelphia, p.177-195.

Money D, 2003. HIV and pregnancy. From: http://www.bcpwaorg/issue6/HIVPreg. htm

Oppenheim JJ, Ruscetti FW. 2003. Cytokines. In: Medical immunology. Tenth ed. Editors: Parslow TG, Stites Op, Terr AI, Imboden JB International edition, San Fransisco, p. 48-166

Rantam, FA, Ferdiansyah, Nasronudin, Purwati. 2009. Stem Cells and Exploration, Airlangga University Press

Sriram B, Rammmesh A. 2008. Human embryonic stemcell (hES) derived dendritic cells are functionally normal and are suspectible to HIV-1 in. AIDS Research and Therapy
Suwendra P. 2002. Human Immunodeficiency Virus. Dalam: Buku Ajar Ilmu Kesehatan Anak infeksi dan Penyakit Tropis. Edisi pertama Editor. Soedarmo S, Gama H, Hadinegoro SR. Ikatan Dokter Anak Indonesia, Jakarta, hlm. 281-302

UNAIDS/WHO. 2000. AIDS epidemic update. Joint United Nations Programe on HIV \& AIDS and World Health Organization, Genewa, p. 1-42

Viviani.B, Corsini E, Binaglia M, Galli CL, Marinovich M (2001). Reactive oxygen species generated by glia are responsible for neuron death induced by human immunodeficiency virus-glycoprotein 120 in vitro. Neurosdence 107: 2-24.

WHO. 2002. The use of antiretrviral therapy: A simplified approach for resourceconstrained countries.WHO regional office for South East Asia, New Delhi, pp. 1-49

Wolf T, Rickerts V, Staszewski S. 2007. First Case of successful allogenic stem cell transplantation in an HIV-patient who acquuuuuired severe Aplastic Anemia. Haematologica, Vol 92, Issue 4, e56-e58 doi 10.3324/haematol.1 1394

Zhang YM, Hartzell C, Narlow M. 2002. Stem cells derived cardiomyocites demonstrate arrytmic potential. Circulation, 106: 1294-99 